\title{
O ADOLESCENTE, O TEMPO E O CONFLITO
}

\section{THE ADOLESCENT, THE TIME AND THE CONFLICT}

Cornelio Pedroso Rosenburg ${ }^{1}$

Rosenburg CP. O adolescente, o tempo e o conflito. Rev. Bras. Cresc. e Desenv. Hum. 2004; 14(3): 11-28.

Resumo: Este artigo trata da importância que assume o fator idade (ou o tempo vivido) para a compreensão da conduta cotidiana do adolescente. O tempo é vital no processo de desenvolvimento integral do homem, ou seja, há diferentes formas de intercâmbio do ser com vários conceitos de tempo, tais como o tempo que passa, o tempo que dura, o tempo vivido, o tempo psicológico. Adolescência e adolescentes são temas amplamente discutidos, notando-se desde logo que e impossível tentar compreender tais etapas da vida em si mesmas, não só porque decorrem de etapas anteriores, mas também porque tem um significado extremamente importante nas que se sucederão. Quanto mais jovem é o indivíduo, mais conjuntural é a construção do seu presente. À medida que ele consegue ter mais vivências, tendo em conta perspectivas mais longas e mais demoradas, gradualmente ele se transforma de ser conjuntural em ser estrutural. Quanto mais jovem, quanto mais inicial é uma adolescência, mais circunstancial e a forma pela qual ela vive e utiliza o seu presente no seu processo de autoconstrução.

Palavras-chave: Adolescencia. Tempo. Conflito.

O tempo é um insumo importante no processo de desenvolvimento integral do homem. A literatura filosófica trabalha distintos conceitos de tempo adotados por diversos autores. Há diferentes formas de intercâmbio do ser com vários conceitos de tempo, tais como o tempo que passa, o tempo que dura, o tempo vivido, o tempo psicológico.

O presente trabalho procura analisar na adolescência a importância que assume o fator idade (ou o tempo vivido) para a compreensão da conduta cotidiana do adolescente.

Adolescência e adolescentes são temas que, a partir de 1950, passaram a ser amplamente discutidos e, daí, gerando imenso número de trabalhos publicados.

Entretanto conceituar ambos os termos constitui-se, até hoje, tarefa extremamente difícil face às múltiplas visões buscando sustentar seus respectivos conceitos.
Certamente, o termo adolescência é uma construção social como em que o autor relata a história evolutiva do referido conceito no decorrer do tempo. Como se pode perceber, o Homem existe há milhares de anos e o conceito de adolescência, poucos séculos.

Com o propósito de discutir alguns aspectos mais relevantes da adolescência, nota-se, desde logo, que é impossível tentar compreender tais etapas da vida em si mesmas, não só porque elas decorrem de etapas anteriores, mas também porque têm um significado extremamente importante nas que se sucederão.

Para se entender uma determinada etapa do desenvolvimento humano, é necessário que se tenha uma percepção do processo da vida como um todo, em toda a sua plenitude. Com esta visão mais abrangente (do processo da vida), pode-se situar melhor as diferentes etapas do desenvolvimento e as características que as distinguem, como

1 Professor Adjunto do Depto. de Saúde Materno-Infantil da Faculdade de Saúde Pública da Universidade de São Paulo e-mail: cprosen@usp.br 
inerentes a um processo contínuo, não fragmentado, em que não existem marcos que diferenciem um momento do outro. Enfatizando, qualquer etapa do desenvolvimento não pode ser entendida de per si e só passa a ter um significado quando inclusa num contexto maior que é o da totalidade do processo da vida.

Iniciar-se-á, então, pela concepção de vida humana, base de todos os raciocínios que aqui serão feitos.

A vida humana é um processo ativo de autoconstrução, resultante da fusão de dois tipos de determinação: de um lado, uma determinação genética que define uma diretriz no caminhar desta vida e, de outro, uma determinação decorrente das relações circunstanciais com as quais o indivíduo interage a cada instante, vinte e quatro horas por dia, todos os dias, permanentemente.

Profundas modificações sofreu o Homem, resultantes das alterações ocorridas no seu processo de auto-construção.

Resultado da evolução, constata-se que, tanto nos seus sistemas fundamentais, assim como na sua duração que, até o século XVII, em média, não ultrapassava os 40 anos, hoje, a expectativa de vida humana atinge os 80 anos.

Esse crescimento da duração da vida não privilegiou a infância, o adulto ou mesmo o velho.

A bibliografia tradicional, que estuda o tema do desenvolvimento, costuma analisá-lo segundo determinadas éticas. O primeiro questionamento, que se pode fazer a essa forma de compreender o desenvolvimento humano, diz respeito à idéia de que esses processos ocorreriam cada um na sua própria dimensão, não guardando entre eles alguma relação. $\mathrm{O}$ estudo do crescimento e o do desenvolvimento é apresentado em capítulos independentes, o que leva a uma interpretação de que o crescimento e o desenvolvimento são dois processos paralelos, que corrreriam um ao lado do outro, com características próprias.

Mas, na realidade, o que se pode perceber é que o chamado estudo do crescimento nada mais é do que a análise das transformações corpóreas que ocorrem durante todo o processo de desenvolvimento, ou seja, é apenas uma das formas de manifestação do referido processo.

O segundo ponto crítico é o da participação das variáveis que interferem nesse desenvolvimento. Elas são normalmente estratificadas e analisadas como elementos bem marcados: por exemplo, a condição social, a qual engloba diferentes enfoques, tais como, o econômico, o cultural, o educacional, etc. Todas estas variáveis elencadas são estudadas procurando-se entender a participação de cada uma delas sobre o processo de desenvolvimento.
O presente estudo pretende abandonar esta forma de interpretação por considerar que nenhuma dessas variáveis atua por si só, independentemente das demais. Por esta razão, procura se substituir esta concepção por outra a qual se denomina Circunstância.

Circunstância consiste na resultante das múltiplas relações das variáveis sociais, ambientais, emocionais, tempo-espaciais entre si, e delas com o indivíduo. Estas relações se alteram a cada instante, permitindo que se tenha uma visão dinâmica do processo. Já se disse que o desenvolvimento humano resulta de duas determinações: uma determinação genética e uma determinação circunstancial. Mas qual a natureza do enlace que une o DNA do indivíduo à sua circunstância?

Normalmente, quando se faz a análise deste processo, tem-se dele uma visão que se poderia chamar de visão física, ou seja, as diferentes variáveis interagindo entre si, mas não perdendo as suas próprias características. Assim, por exemplo, se num recipiente misturaram os hidrogênio e oxigênio, haverá uma interação entre os dois, porém cada um deles conservando as suas características próprias.

Mas, no caso do desenvolvimento humano, a natureza do elo entre as variáveis não é física, pois elas não se misturam apenas. O enfoque tem que ser outro tem que ser químico. Tomando o mesmo exemplo, hidrogênio e oxigênio, agora numa reação química em que eles se combinam, o resultado não será mais uma simples mistura. Teremos um produto diferente. Teremos água.

Do mesmo modo, como é impossível entendermos as propriedades da água conhecendo apenas o hidrogênio e o oxigênio, também não é possível compreendermos a molécula de água sem conhecermos o que é hidrogênio e o oxigênio. E, curiosamente, estes dois elementos, que se caracterizam por serem altamente inflamáveis, quando combinados formam a água, que é o oposto do fogo.

É preciso ter esta visão química para que se possa entender o papel do desenvolvimento como um processo ativo, autoconstrutivo, em que a criança vai incorporando (a si própria) as circunstâncias com as quais convive e com as quais interage. E é esta capacidade do Homem incorporar ao seu todo a circunstância em que vive que caracteriza e diferencia o Homem dos demais seres vivos da Natureza.

O tempo é algo estranho, quase misterioso. Santo Agostinho dizia ser capaz de medi-lo, sentí-lo e vivê-lo, mas se mostrava perplexo ao tentar definir o que seria o tempo.

O tempo pode ser avaliado e entendido de várias formas. A mais simples e costumeira é a de 
conceituar o tempo como um contínuum entre as suas três dimensões: alguma coisa que já aconteceu, algo que está acontecendo e algo que ainda acontecerá. O passado, o presente e o futuro. Quando se diz que o passado é tudo o que já aconteceu e o futuro é tudo o que ainda vai acontecer, o presente passa a ser aquele instante ideal em que o futuro se transforma em passado. Perplexos, como Santo Agostinho, acaba-se por concluir que o presente é uma abstração! E ainda mais, se o presente é uma abstração, “ eu também sou uma outra abstração, pois vivo nela!”

Como o Homem não se pode entender como ser abstrato, passa a trabalhar com uma outra concepção de tempo. Não mais um tempo que passa, mas um tempo que permanece. Só assim se pode entender o presente, porque o presente nunca passa, o presente dura, enquanto dura a vida. O que passa são as experiências e as vivências, mas o presente está sempre presente.

Contudo, a forma pela qual cada um usa o seu presente no seu processo de auto-construção depende de certas características que são próprias de cada uma das etapas do desenvolvimento humano, uma vez que a participação do tempo, no processo de auto-construção, não é uniforme.

Assim é que a forma pela qual cada um constrói o seu presente fica na dependência de como utiliza o passado e o futuro na elaboração do seu próprio presente, a cada instante que se vive, sendo o resultado de um passado que se projeta e que se organiza em função de uma perspectiva futura. Da fusão desses dois elementos, é que se constrói o presente. Há de se perceber, portanto, que, de acordo com as etapas da vida, o significado de um passado e o significado de um futuro são extremamente variáveis porque decorrem do número de vivências que o indivíduo vai acumulando durante o caminhar de sua própria existência.

Nos primeiros meses ou mesmo nos primeiros anos de vida, o número de vivências que se acumula é extremamente limitado e, por isso, as perspectivas de futuro são muito reduzidas. Qualquer um que tenha tido a oportunidade de conviver com crianças pré-escolares, verifica que a sua capacidade de projeção futura é extremamente limitada. Um futuro longo para uma criança de 4 anos não ultrapassa, na maioria das vezes, alguns dias ou algumas semanas. Tudo o que ela faz está ligado a uma perspectiva futura que não transcende horas, dias ou, no máximo, semanas.

Para isto também concorre o chamado tempo vivido que interfere na forma da composição do presente. Cada um dimensiona o seu tempo em função da sua própria vida vivida, ou seja, para se imaginar uma criança de 4 anos com capacidade de projetar um futuro de um ano seria preciso que ela tivesse como perspectiva o equivalente a $25 \%$ do seu tempo vivido. Não é por outra razão que, à medida que se envelhece, o tempo parece correr mais depressa. A percepção de tempo futuro encurta porque se vai significando esse tempo em função do tempo vivido e, quanto mais vivido, menos significado tem 1 dia ou 2 .

$\mathrm{O}$ conjunto das experiências vividas permite trabalhar com uma nova visão de tempo e espaço, de maior profundidade. Quanto menos rico for este número de vivências e quanto mais limitada for a perspectiva de projeções do futuro, mais o resultado do presente se prenderá ao momento do hoje, ao agora. Ou seja, o momento que está sendo vivido agora é o momento que interessa. Quanto mais jovem é o indivíduo, mais conjuntural é a construção do seu presente. E a construção do presente define a sua forma de ser, a sua forma de agir, a sua forma de reagir, a sua forma de incorporar, a sua forma de se auto-construir. O jovem é o presente.

À medida em que ele consegue ter mais vivências, começa a ter uma perspectiva de construir o seu presente, tendo em conta perspectivas mais longas e mais demoradas; gradualmente ele se transforma de ser conjuntural em ser estrutural.

Voltando ao desenvolvimento, que é preocupação maior, percebe-se, com grande facilidade, que, quanto mais jovem, quanto mais inicial é uma adolescência, mais circunstancial é a forma pela qual ela vive e utiliza o seu presente no seu processo de auto-construção. O significado do hoje, do agora, transcende em termos de valor, em termos de importância, em termos de autosatisfação.

Curiosamente, as pessoas que participam da circunstância dos adolescentes, isto é, os adultos, quer sejam seus pais ou responsáveis, dificilmente conseguem ver estes adolescentes dentro de uma ética conjuntural. A representação e o significado do adolescente para os adultos, principalmente para os pais, estão sempre dentro de uma ética estrutural. Os pais não valorizam o hoje, o agora, os pais valorizam o futuro. O presente está, segundo a ética paterna, vinculado às perspectivas futuras e que pouco dizem ao seu adolescente.

No processo de desenvolvimento, a capacidade de discernimento vai também se auto-construindo gradualmente. Numa etapa pré-escolar, essa capacidade se limita à exploração máxima de uma crítica analógica, ou seja, a criança é capaz, na idade pré-escolar, apenas de uma crítica por comparação, no limite do domínio de uma lógica analógica, que lhe permite se inserir, sem grande conflito existencial, com as pessoas adultas. 
Entretanto, superada ou atingida a etapa em que a criança passa a se iniciar no domínio da lógica matemática, o que Piaget chamou de reversão do pensamento, ela passa a ter uma capacidade crítica de julgar o certo e o errado.

A reversão de pensamento é a capacidade da pessoa entender que, se A é igual a B e B é igual a C, logo C é igual a A, ou seja, é a capacidade de começar a trabalhar com os instrumentos da lógica matemática que se chama silogismo. $\mathrm{O}$ silogismo é o instrumento que dá a cada um, que o usa, a certeza de que as suas conclusões são as conclusões verdadeiras.

Contudo, na dependência da validade da premissa da qual se parte, estas conclusões nem sempre ou muitas vezes não nos levam a resultados lógicos certos.

O adolescente, silogisticarnente, constrói as suas verdades a partir de uma premissa conjuntural, o que o levará a conclusões absolutamente certas e verdadeiras, porém, tendo como base apenas as circunstâncias.

Para os pais, a situação é outra. Partindo de outra premissa, estrutural, silogisticamente também, chegarão a conclusões absolutamente diversas dos seus adolescentes. E aí está a gênese do conflito.

Enquanto para o adolescente é muito mais importante satisfazer uma necessidade circunstancial - como jogar bola, ir ao shopping, namorar para os pais nada disso tem importância, ou só tem importância se não interferir na sua formação, na estrutura da sua vida. São verdades diferentes. Da forma pela qual cada um constrói a sua verdade e da certeza que tem dessa própria verdade surge o conflito.

E por que o conflito entre pais e filhos se estabelece? E por que a relação avô e neto é, na maioria das vezes, muito mais tranqüila?

Ao responder à segunda pergunta, estarse-á encaminhando para entender a primeira.

- À medida em que se envelhece, o presente já não tem mais a mesma probabilidade de se projetar a longo prazo, o que nos leva a, gradualmente, desvalorizar a vida estruturada e, cada vez mais, valorizar a conjuntura no presente vivido.

Por exemplo, dificilmente, se poderia, com 83 anos de idade, fazer projetos e construir toda a vida, visando situações para daqui a 10 ou 15 ou 20 anos, já que a perspectiva da duração deste presente não chega até lá. Razão pela qual aí se passa a valorizar o hoje, o agora, a conjuntura. E, na medida em que se começa a valorizar mais a conjuntura do que a estrutura da vida, começa-se a se aproximar dos jovens e das crianças. Portanto, não há nenhum mistério em se explicar por que a relação avô e neto se faz de uma maneira muito mais tranqüila do que a relação pai e filho.
Pais extremamente severos, exigentes para com seus filhos se tornam avós absolutamente compreensivos, avós que se revoltam com as atitudes dos pais reclamando da sua postura frente aos seus filhos: "Deixe o menino em paz", "O coitado não pode fazer nada", "Você fica em cima dele o dia inteiro". Esquecem-se da relação conflituosa que tiveram, quando pais, com seus filhos.

O conflito se estabelece, por um lado, pela incapacidade do próprio adolescente, por não estar devidamente instrumentado ainda, de tentar ver a sua própria realidade sob outras óticas; por outro lado, pelo despreparo dos adultos que, dispondo dessa capacidade, não sabem como usá-la no sentido de entender e dialogar com o adolescente.

A proposta de diálogo é universal e é extremamente comum ouvir de pais, que conflitam com seus filhos adolescentes, dizer que buscam resolver os seus problemas e seus conflitos pela prática do diálogo. Mas de que "diálogo" estão falando?

Este "diálogo" se faz num nível que é absolutamente contrário ao da própria essência do diálogo, ou seja, é um confronto das conclusões lógicas diferentes, obtidas pelo adolescente de uma parte, e pelos adultos de outra. Conclusões lógicas que são por ambas as partes estruturadas e classificadas, segundo a valorização de cada um deles. Os adultos ainda não aprenderam que os valores não são melhores e nem piores, eles são apenas diferentes. Como neste "diálogo" ninguém abre mão das suas valorizações e, conseqüentemente, de suas verdades, a solução do confronto se dará pela disponibilidade do poder. Se os adultos tiverem mais poder, sua verdade será imposta. Se o adolescente tiver o poder maior, ele impõe a sua verdade.

No caso de não poder impor a sua própria vontade, o adolescente, até por uma questão de força ou de impotência, vai reagir das mais diferentes formas, quer seja afastando-se do meio familiar com o qual ele não concorda ou assumindo, por exemplo, atitudes simulatórias, mentirosas, que tentam apenas neutralizar o efeito da autoridade. A mentira ou a fuga do meio familiar, o distanciamento de pais e filhos é o produto de tal "diálogo".

O que os adultos precisariam fazer é compreender o conceito de diálogo. Diálogo significa adesão a uma idéia, não imposição ou subordinação a uma idéia imposta sob o regime da força.

Neste sentido, é preciso que os adultos desloquem o cerne das discussões do confronto das conclusões lógicas para o confronto das premissas das quais ambas as conclusões foram obtidas.

Com o reconhecimento de que as premissas não são as mesmas, é preciso entender 
as suas diferenças. Só a partir daí se pode imaginar um diálogo verdadeiro que pode resultar no estabelecimento de novas premissas que atendam às características diferentes de ado- lescentes e adultos, pais e filhos. Disso resultam novas verdades que permitem uma adesão mútua, no sentido de superar suas próprias diferenças.

\begin{abstract}
This article focuses on the importance of age (or lived time) to the comprehension of adolescents' daily behavior. T me is essential to the integral process of human development, that is, there are different forms of exchange between the being and diverse concepts of time, such as: time that passes away, time that lasts, lived-time, psychological time. Adolescence and adolescents are themes widely discussed,- and it is impossible to understand these stages of life in among themselves, not only because they developed from precedent stages, but also, they have a strong meaning to the ones that will follow. The younger the person is, the more conjuctural the construction of the present. To measure that he/she achieves more experiences, taking in account longer and lasting perspectives, he/she gradually transforms himself/herself from a conjunctural to a structural being The more frequent these experiences are at the beginning stages of adolescence, the more circumstantial is the way he/she lives and uses his/her present in the selfconstructión process.
\end{abstract}

Key words: Adolescence. Time. Conflict. 